\title{
Archaeological Testing of the Reading Site, Site 41BU16 Burleson County, Texas
}

Joe T. Denton

Follow this and additional works at: https://scholarworks.sfasu.edu/ita

Part of the American Material Culture Commons, Archaeological Anthropology Commons, Environmental Studies Commons, Other American Studies Commons, Other Arts and Humanities Commons, Other History of Art, Architecture, and Archaeology Commons, and the United States History Commons

Tell us how this article helped you.

This Article is brought to you for free and open access by the Center for Regional Heritage Research at SFA ScholarWorks. It has been accepted for inclusion in Index of Texas Archaeology: Open Access Gray Literature from the Lone Star State by an authorized editor of SFA ScholarWorks. For more information, please contact cdsscholarworks@sfasu.edu. 


\section{Archaeological Testing of the Reading Site, Site 41BU16 Burleson County, Texas}

\section{Licensing Statement}

This is a work produced for the Texas Department of Transportation (TxDOT) by the report producer. TxDOT and the report producer jointly own all rights, title, and interest in and to all intellectual property developed under TXDOT's contract with the report producer. The report may be cited and brief passages from this publication may be reproduced without permission provided that credit is given to both TxDOT and the report producer. Permission to reprint an entire chapter, section, figures or tables must be obtained in advance from either the Supervisor of the Archeological Studies Branch, Environmental Affairs Division, Texas Department of Transportation, 125 East 11th Street, Austin, Texas, 78701 or from the report producer. 
ARCHAEOLOGICAL TESTING OF THE READING SITE, SITE 41 BU16

BURLESON COUNTY, TEXAS

B y

Joe T. Denton

Texas

State Department of Highways and Public Transportation

Highway Design Division

October 1983 


\begin{abstract}
Construction activities during the replacement and upgrading of the State Highway 21 bridge over the Brazos River in Burleson County uncovered a previously unknown portion of archaeological Site 41BU16, the Reading Site, within the State Department of Highways and Public Transportation (SDHPT) right-of-way •

Efforts by local concerned citizens resulted in the salvaging of one partially intact burial and the notification of the SDHPT cultural resources staff.

Evidence recovered during SDHPT testing indicates that the area was occupied over an extensive period of time from the Archaic Period to the Late Prehistoric Period. Also indicated is a late nineteenth and early twentieth century settlement. No additional burials were recovered during the testing.

Evidence from the testing demonstrates that sufficient materials are present to warrant the nomination of Site 41BU16 to the National Register of Historic Places.
\end{abstract}




\section{INTRODUCTION}

Archaeological Site 41BU16, the Reading Site, was reported in February, 1972, by Mr. Bill Moore who recorded the site with the Texas Archeological Research Laboratory. Location for the site was indicated to be west of the Southern Pacific railroad tracks which parallel State Highway 21 to the west, thus placing the site beyond the State Highway 21 right-of-way (Fig. 1). A subsequent survey by a member of the State Department of Highways and Public Transportation (SDHPT) archaeology staff in October, 1974, did not find any indication of the site due to heavy vegetation.

Based on this information, archaeological clearance for the project was granted under provisions that any cultural material unexpectedly encountered during construction would be investigated in accordance with Procedures for the Protection of Historic and Cultural Properties (36 CFR, Part 800), procedures which are prescribed and endorsed by the Federal Highway Administration.

Notification received on August 25, 1983, by the SDHPT cultural resources staff that cultural remains, specifically a prehistoric human burial, had been encountered prompted the testing of the remaining portion of the site. Testing to determine the scope of damage to the site and to determine eligibility to the National Register of Historic Places was performed on September 6 through 16, 1983. Testing was conducted as prescribed by federal mandate and endorsed by the Federal Highway Administration.

Testing was conducted by the author and two SDHPT personnel, one from the Bryan residency office and one from the Caldwell residency office.

Testing objectives were to assess the damage that occurred during construction and to determine the site depth, cultural context, and archaeological significance of the remaining cultural deposits within the SDHPT right-of-way. 
This Page Redacted Per THC Policy 


\section{SITE DESCRIPTION}

The highway project consists of the construction of two new bridge structures allowing two two-lane, one-way crossings of the Brazos River and the realignment and upgrading of S.H. 21 to a full-standard, two lane facility (Fig. 2). Construction of the east-bound lanes will be on new location and the west-bound lanes will be at the present site of the Brazos River Bridge (Fig. 3) .

The existing bridge is a narrow $22 \mathrm{ft}$. structure, 1,186 $\mathrm{ft}$. long, with a vertical clearance of $15 \mathrm{ft}$. $11 \mathrm{in}$. The structure is a through-truss span facility of steel I-Beam and treated timber construction. The bridge has been determined not to meet the criteria for inclusion within the National Register of Historic Places.

The archaeological site, 41BU16, also known as the Reading Site, is located on the south bank and high terrace of the river on an upland point of land above the Brazos River valley (Fig. 1). Cultural evidence is scattered over a wide area from roughly 200 feet west of the Southern Pacific Railroad tracks to $200 \mathrm{ft}$. east of S.H. 21 (Fig. 2). A 11 that remains of the site within the highway right-of-way is a strip of land approximately $220 \mathrm{ft}$. north-south by $40 \mathrm{ft}$. east-west (Fig. 2). Because of lack of supportive data and prior disruption to the area from both railroad and highway construction activities, it is uncertain if the remaining cultural evidence represents one site or if it in fact represents several sites.

Depth of the cultural deposits varies from shallow to deep over the area, with increasing depth apparent along the edge of the terrace, particularly in the area east of the old Highway 21 bridge. This information is based primarily on the observations by an SDHPT project inspector from the SDHPT Bryan residency office. A dark soil was observed by the project inspector without the realization that it was in fact a cultural or midden deposit. Profiles made by the SDHPT cultural resources staff during testing indicate a possible midden depth in excess of $\mathbf{1}$ meter in the area of the new bridge. 


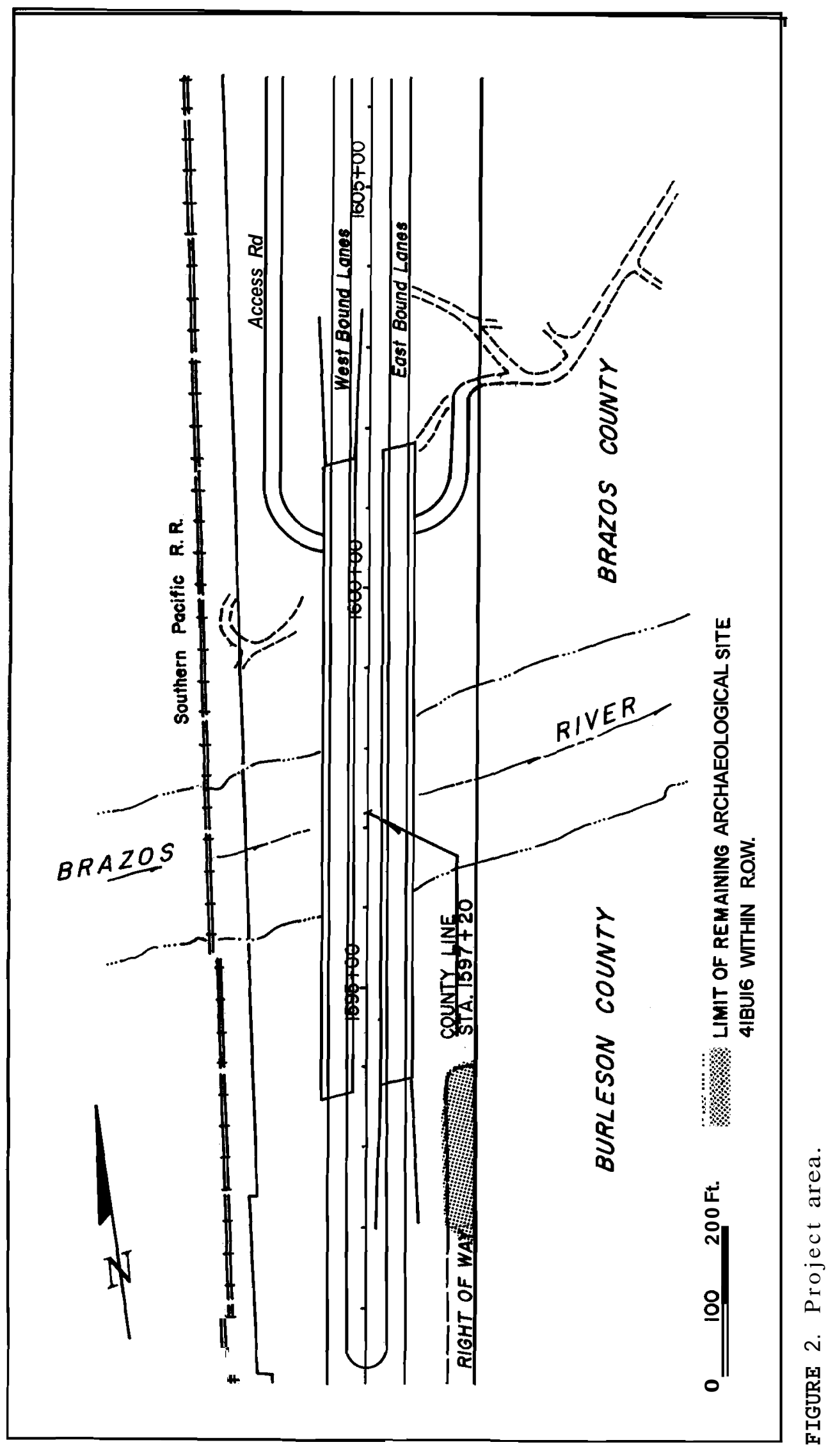


The site prior to construction was obscured by a heavy vegetation cover which created some disruption to the shallow portions of the site during clearing operations. Vegetation along the Brazos River bottomland consists of oak, ash, elm, pecan, willow, and sycamore. Much of the area today has massive thick growths of understory plants.

The site when tested was covered with grasses and vines and had few open areas of exposed surface. Heavy growth of vines and tall weeds which are principally ragweed predominate in areas outside of the right-of-way. 
ARCHAEOLOGICAL BACKGROUND

Geographically, the Reading Site, 41BU16, is located on the eastern periphery of the Central Texas Archaeological Region as defined by Suhm (1960: 63). This area is defined as containing the middle stretches of both the Colorado and Trinity Rivers and a 11 their tributaries. Artifact assemblages on the southeast periphery typically reflect strong cultural ties to the central portions of Texas, with some traits common to areas to the east and south.

Archaeological research has been conducted to the north, south, east, and west, which provides insight into the expected cultural affiliations of the Reading Site.

Reports of reservoir surveys and testing provide the primary data related to the region. Excavations at Lake Limestone (Prewitt 1975) produced some evidence to suggest that the area was occupied by populations that were influenced by or related to cultures adjacent to the Upper Navasota River valley.

Excavations at Lake Conroe to the southeast of the present study area suggest that the main cultural affiliations at Lake Conroe were to the east and northeast, with some influences from the coastal areas (Shafer 1968).

Of primary importance to the understanding of the Reading Site is the archaeology of Lake Sommerville and specifically the Erwins Bridge Site. This site is located some $20 \mathrm{miles}$ south of the Reading Site. The data recovered indicate that cultural affiliation was greatest between this area and the Central Texas region. There were also some cultural influences to the east and south (Peterson 1965). 


\section{PROCEDURES}

Testing to determine the extent of construction-related damage and significance of the cultural deposits remaining was facilitated through the use of hand-excavated 1 by 2 meter and 2 by 2 meter test units and profiles cut into the existing surfaces.

A base line was established parallel to the SDHPT right-of-way with metric divisions for horizontal control. The grid system was tied to the SDHPT stations and coordinates. Excavation proceeded in $10 \mathrm{~cm}$ levels with the exception of an upper mixed zone which was removed as one level. The soil from each level was screened through $1 / 4 \mathrm{in}$. hardware cloth, and all cultural material was retained. The material from each level was placed in separate bags marked as to unit and level. Analysis and storage of the materials was concluded at the SDHPT archaeology laboratory in Austin.

Test Unit 1 was placed proximal to a previous relic hunter's excavation and the burial area (Fig. 3). This unit was a 2 meter square. Test Units 2 through 4 were 1 by 2 meter units oriented north-south. 


\section{SOIL MORPHOLOGY}

Soils within the area tested consist of a sandy loam which overlies a red sandy clay. The sandy loam in the downslope areas of sufficient deposits exhibits stratigraphic divisions which are lost or nonexistent in the shallower upslope deposits. Much of the soil in the area tested had been disturbed by brush clearing and by rodent activity.

Soil stratigraphy, defined primarily on the basis of Profile 2 (Fig. 4) and Test Unit 1 (Fig. 5), indicates that four zones are present above the basal clay.

Zone A: Zone A is a mixed zone of sandy loam and red clay varying in thickness. Thickness ranges from 1 to $28 \mathrm{~cm}$. This zone contains both recent and prehistoric cultural material.

Zone B: Zone B is a sandy loam zone, generally loose and of varying thickness. It ranges from 2 to $20 \mathrm{~cm}$ thick. This zone evidences recent disruptions to the site and often is separated from Zone $\mathrm{C}$ by a thin layer of grass and rootlets from the original ground surface. Cultural material also is mixed in this zone.

Zone C: Zone $\mathrm{C}$ is sandy loam, very dark and hard when dry. This zone varies in thickness from 10 to $15 \mathrm{~cm}$ on the upslope areas away from the river to a thickness of $\mathbf{1 . 1}$ meters dounslope nearer the river. This zone is largely undisturbed by recent activities but does have numerous rodent burrows. Where the zone is in excess of $50 \mathrm{~cm}$ thick, there is a division between the upper and lower parts. 


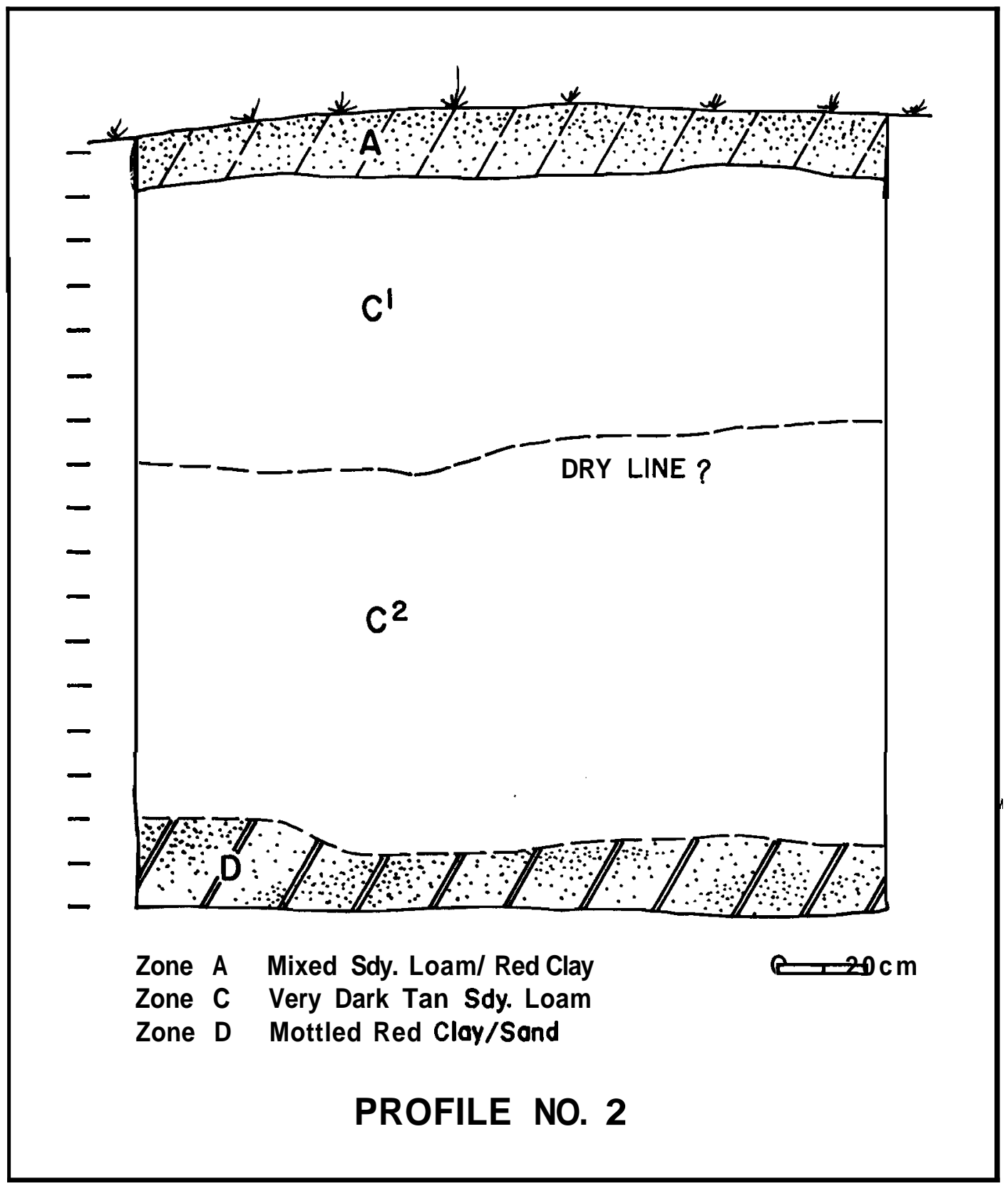

FIGURE 4. Soil zones present in Profile 2. 


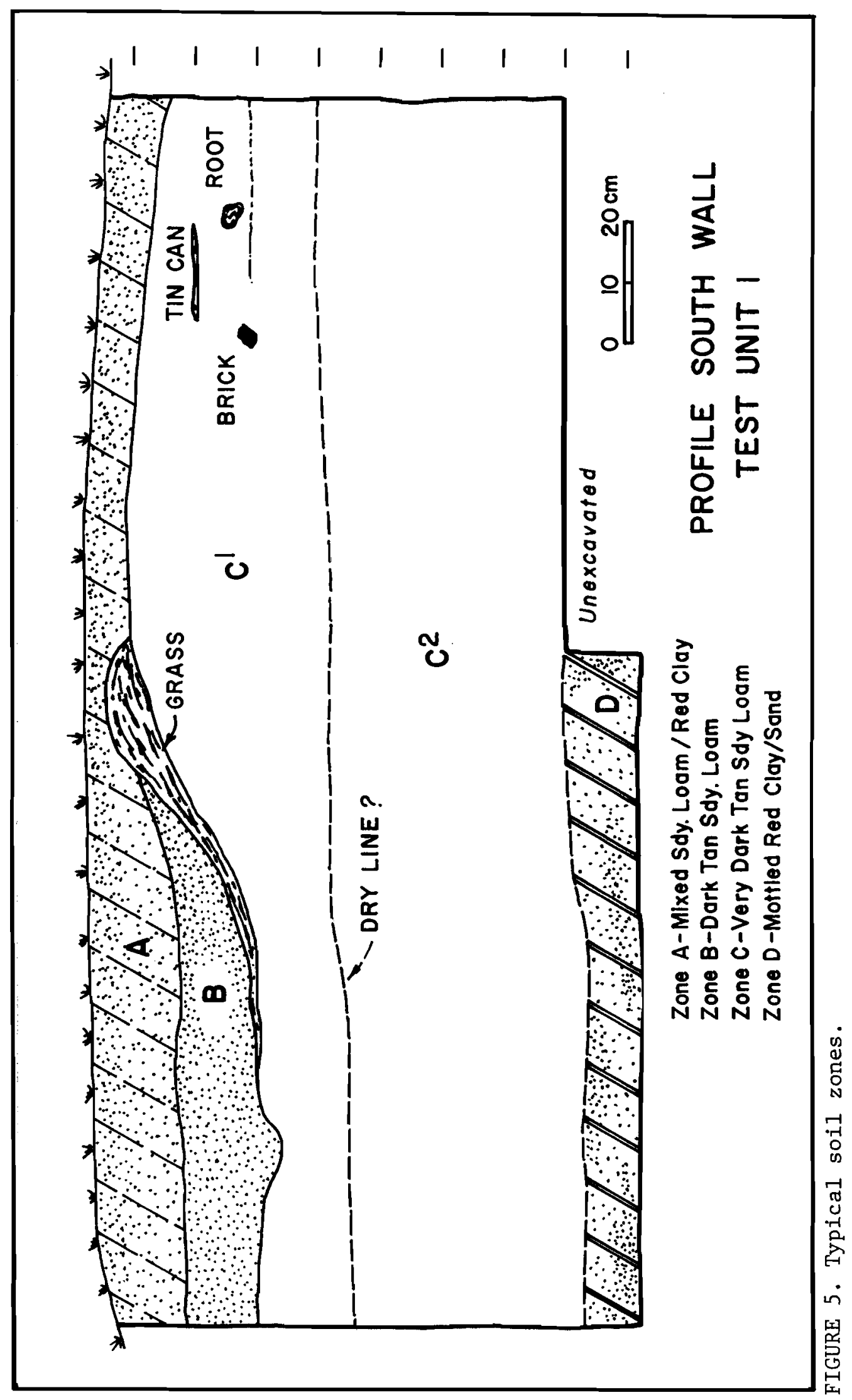


The lower zone is slightly lighter in color and somewhat mottled. Historic artifacts as well as prehistoric materials are present in the upper portion of the zone. Prehistoric materials are present in the lower zone.

Zone D: Zone D is a sandy clay mottled red orange deposit, very stiff when wet and hard when dry; it dries to a light burnt orange color. This zone varies in depth below surface of 50 am upslope to 1.5 meters downslope. This zone contains a few flakes.

Zone E: Zone $\mathrm{E}$ is a sandy clay, red orange in color; it is very stiff when wet and hard when dry. No known cultural debris is contained within the deposit. This zone begins at $50 \mathrm{~cm}$ below surface upslope and 1.6 meters downslope. 


\section{ARTIFACTS}

A total of 47 artifacts was recovered as a result of the SDHPT archaeological testing. Artifacts include projectile points, bifaces, modified flakes, cores, a metate fragment, debitage, pottery, and historic artifacts. Historic artifacts include metal artifacts, glass, and ceramics.

\section{Projectile Points}

Projectile points include 2 dart points, 4 dart point fragments, 3 arrowpoints, and $\mathbf{3}$ arrowpoint fragments. Each nearly complete or complete specimen is described individually; the remainder are described as a group.

\section{DART POINTS}

\section{Specimen 1 (Fig. 6A)}

This projectile point fragment appears to have been broken during manufacture. The blade is slightly expanding and one edge exhibits retouch of platform preparation, where a snap fracture occurs. The specimen exhibits slight barbs, and the stem is straight with slightly contracting sides. The base is straight and wedge-shaped in profile. Maximum thickness of the specimen, $1.0 \mathrm{~cm}$, is at the juncture of the stem and blade. Maximum width of the blade is $40 \mathrm{~mm}$. This specimen is similar to those described as Bulverde by Suhm and Jelks (1962). Provenience is Test Unit 1, Level 5.

Specimen 2 (Fig. 6B)

This specimen is the only complete projectile point recovered during the test. It, like Specimen 1, is incompletely manufactured. The blade edges are uneven and were formed by percussion and retouch primarily on the dorsal surface of the flake blade. The shoulders are rounded, and the stem is formed by sharply converging sides to a rounded base. Bifacial work is evident on the tip and lateral edges of the flake. The specimen is $41 \mathrm{~mm}$ 


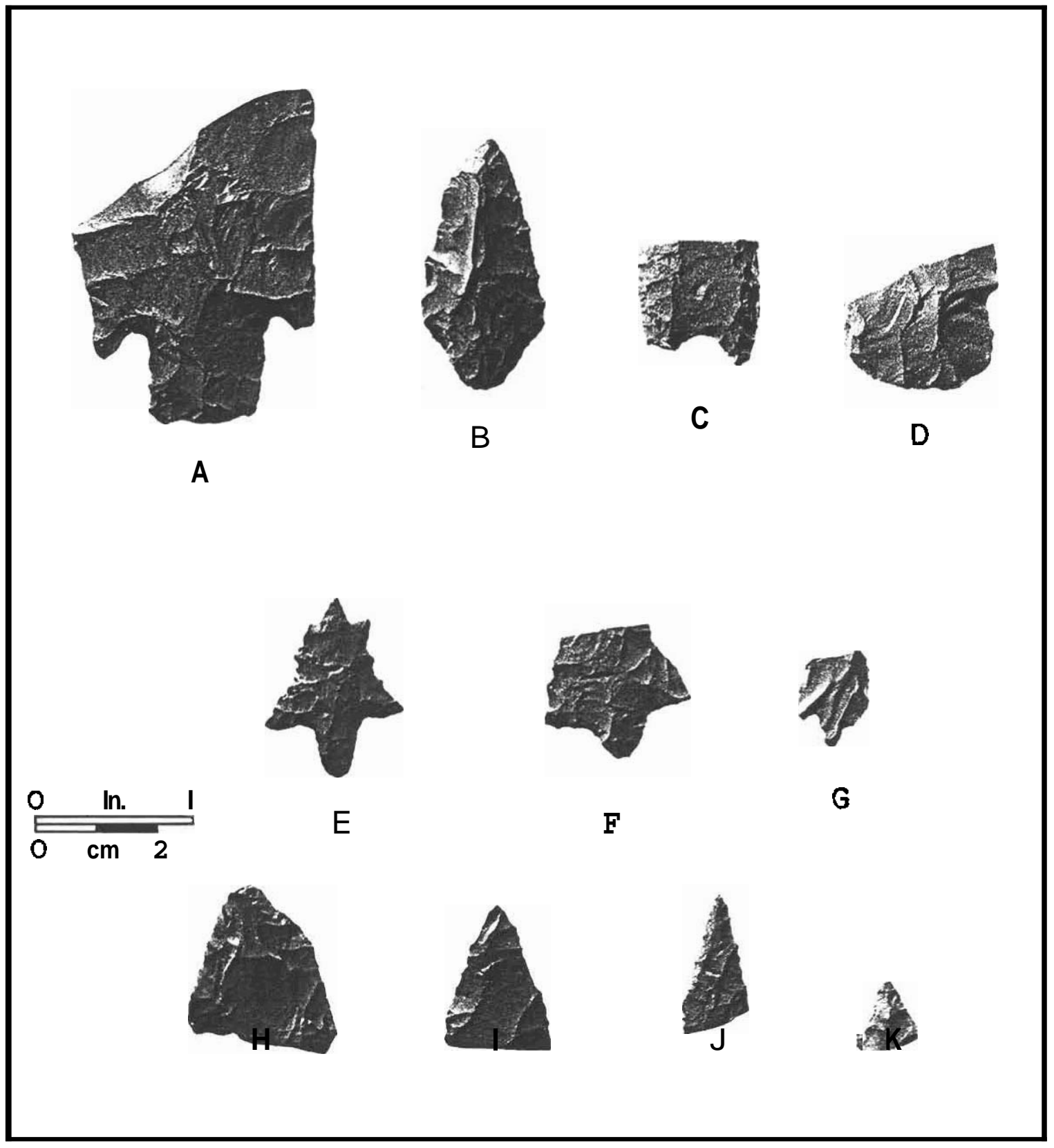

FIGURE 6. Projectile points. A, Bulverde-like; B, Gary-like; C, Pedernales-like; D, probable dart point preform; E, Perdiz; F, G, arrowpoint fragments; $\mathrm{H}-\mathrm{K}$, projectile point fragments. 
long and $20 \mathrm{~mm}$ wide, with a maximum thickness of $6 \mathrm{~mm}$. Although the manufacture is incomplete, this point is tentatively classified as a Gary (Suhm and Jelks 1962). Provenience is Test Unit 3, Level 1.

Specimen 3 (Fig. 6C)

This projectile point stem has straight to slightly recurved sides, with sharply beveled, retouched edges. The base is deeply U-shaped. The stem closely resembles the Pedernales type as described by Suhm and Jelks (1962). Provenience is Test Unit 2, Level 3.

Specimen 4 (Fig. 6D)

This fragment is being considered as a projectile point although it does not represent a stemmed point. The specimen appears to be a dart point preform. It is thinned by soft-hammer percussion overall, with some edge retouch. Thickness is $4 \mathrm{~mm}$; maximum width is $24 \mathrm{~mm}$. Provenience is Surface.

\section{ARROWPOINTS}

Specimen 1 (Fig. 6E)

This nearly complete specimen has concave blade edges with flaring barbs. The blade edges are slightly serrated with two forward-flaring projections slightly below the distal tip. One projection has been broken. The stem is contracting to a rounded base. The specimen is completely bifaced, and workmanship is excellent. Length is $29 \mathrm{~mm}$, width is $22 \mathrm{~mm}$, and stemlength is $9 \mathrm{~mm}$. This arrowpoint has been classified as Perdiz (Suhm and Jelks 1962). Provenience is Test Unit $\mathbf{1}$, Level 3.

\section{Specimen 2 (Fig. 6F)}

This specimen is completely bifaced with slightly concave blade edges. The barbs are flaring with straight shoulders. The stem edge sharply converges to a pointed base. Width is $24 \mathrm{~mm}$, ste m width is $10 \mathrm{~mm}$, and length is $6 \mathrm{~mm}$. Provenience is Test Unit 1, Level 2. 
Specimen 3 (Fig. 6G)

This fragment is marginally considered as an arrowpoint. Principally, it comprises a broken flake with retouch to form a small stem and barb. The edges also have been retouched and are uneven. The flake is thin, less than $2 \mathrm{~mm}$ in thickness. The fragment is too incomplete to be typed. Provenience is Test Unit 4, Level 1.

\section{RAGMENIS}

A total of five projectile point fragments was recovered (Fig. 6H-K). There were two that could be considered dart point fragments and three that were arrowpoint fragments.

Other Bifaces

AWL OR PERFORATOR (Fig. 7A)

The bit of this tool is totally bifaced and is thick relative to its width. There is no apparent edge wear.

\section{THINNED BIFACES}

Specimen 1 (Fig. 7B)

This fragment appears to be a corner of a straight-based biface. The base and side roughly form a right angle and each has a straight and retouched edge. Although too fragmentary to type accurately, the specimen appears to be similar to the Friday knife as described by Jelks (1962:42). Provenience is Test Unit 1, Level 5.

Specimen 2 (Fig. 7C)

This fragment, a proximal and lateral portion of a rounded-based, parallelsided knife, is similar to the Covington knife as described by Jelks (1962: 


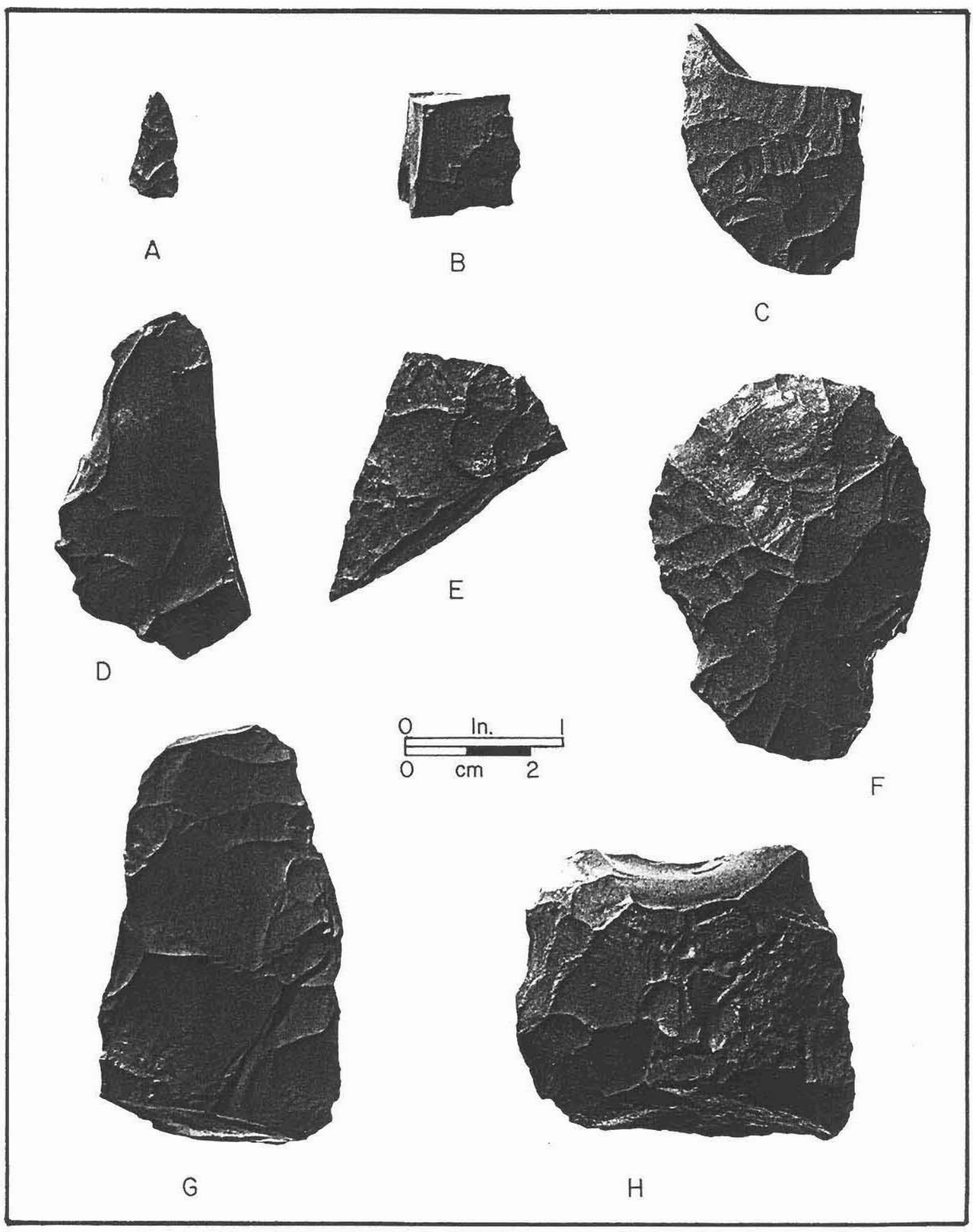

FIGURE 7. Bifaces. A, awl or perforator; B-E, thinned bifaces; F-H, thick bifaces. 
42). The location and presence of an inclusion within the material, along with partial retouch, suggest that this biface broke during manufacture. Provenience is Test Unit 1, Level 3.

Specimen 3 (Fig. 7D)

This specimen is a fragment with uneven, unretouched edges. Overall shape appears to be roughly subrectangular; the specimen has an oblique fracture across one side and end. Soft-hammer percussion is indicated over a 11 the surfaces. Length is $52 \mathrm{~mm}$, and thickness is $10 \mathrm{~mm}$. Provenience is Test Unit 1, Level 2.

Specimen 4 (Fig. 7E)

This specimen is a medial biface fragment with even retouched edges. Blade edges are sharply converging. Snap fractures occur at inclusions in the material. Provenience is Test Unit 1, Level 5.

\section{THICK BIFACES}

Specimen 1 (Fig. 7F)

This specimen has rounded distal edges and sides. Edges are even but lack retouch. There is a slight indentation on the proximal end that suggests hafting. Length is $63 \mathrm{~mm}$; width is $45 \mathrm{~mm}$; thickness is $18 \mathrm{~mm}$. Provenience is Test Unit 4, Level 2.

Specimen 2 (Fig. 7G)

This specimen is a fragment with deep flake scars and some cortex on the dorsal surface. Some edge evening on one lateral edge is present. The specimen appears to have been manufactured from river cobble. Provenience is Test Unit 4, Level 2. 
Specimen 3 (Fig. 7H)

This specimen is a fragment with some cortex on one surface. Edges are sinuous and unretouched. A large crystal inclusion in the material apparently contributed to one fracture. An opposite fracture appears gougelike but is ill defined. Provenience is Test Unit 1, Level 4.

\section{BIFACE FRAGMENIS}

Nine biface fragments were recovered including four distal tips, 4 lateral fragments, and $\mathbf{1}$ medial section. All but two are fragments of thick bifaces.

\section{Modified Flakes}

Seven modified flakes were recovered. The area of modification is primarily on the lateral edges. Two show only slight modification. The flakes are a $11 \mathrm{small}$ and thin; they range from $2.2 \mathrm{~cm}$ in length to $4 \mathrm{~cm}$ in length. A 11 widths are less than $3.5 \mathrm{~mm}$. One fragmentary piece exhibits steep beveling-approximately $52^{\circ}$ to the ventral surface. No polish or wear of edges was noted.

\section{Cores}

A total of eight cores was recovered, all of which appear to be of local gravels. Flaking is generally random and ranges from the removal of a few flakes to nearly exhausted nodules.

\section{Metate Fragment}

One ground stone artifact was recovered from the surface. This metate fragment is a coarse-grained sandstone slab with one face smoothed. The 
fragment is $17 \mathrm{~cm}$ long, $10 \mathrm{~cm}$ wide, and $4 \mathrm{~cm}$ thick, and probably represents a quadrant of the total metate.

\section{Debitage}

A total of 2710 flakes was recovered, of which $76 \%$ came from Test Units 1 and 4 .

\section{Pottery}

Two small prehistoric potsherds were recovered, both of which exhibit no decoration. Both appear to have sandy paste with no additional temporing agents. One is $3 \mathrm{~mm}$ thick; the other $6 \mathrm{~mm}$ thick. Provenience is Test Unit 1, Level 2, and Test Unit 4, Level 2.

\section{Historic Materials}

With the exception of the shallow units, Test Units 2 and 3, a 11 historic materfal was recovered from the upper portions of the soil zones. Fifty percent of the historic material was contained in Level 1.

Historic material includes 415 glass fragments of clear bottle and window glass, green, amber, blue, and white glass. Some of the clear glass has begun to patinate and to turn purple.

Other historic material includes both wire and cut nails, wire, and parts from machinery including gasoline motor parts. Some household implements including a spoon fragment and ceramics are also included. 


\section{BURIAL AND NONARTIFACTUAL MATERIALS}

Portions of the burial that were recovered by the avocational archaeologists, along with a photograph and verbal description, indicate that the burial was shallow, less than 40 an deep, and contained no grave goods. Allowing for some surface disturbances, it is presumed that the burial was associated with the Late Prehistoric Period. Figure 8 is an SDHPT drawing of the burial made from a photograph furnished by the avocational archaeologists and based on information supplied by them. Additional burial data are presented in the Appendix.

Also recovered during the testing were several bone fragments. Most of the bone is unidentifiable; however, at least two species were present. One fragment of a large animal was recovered from Level 4 of Test Unit 1 which presumably is of Bos species. Also recovered in Test Unit 1, Level 5, was a deer astragalus. 


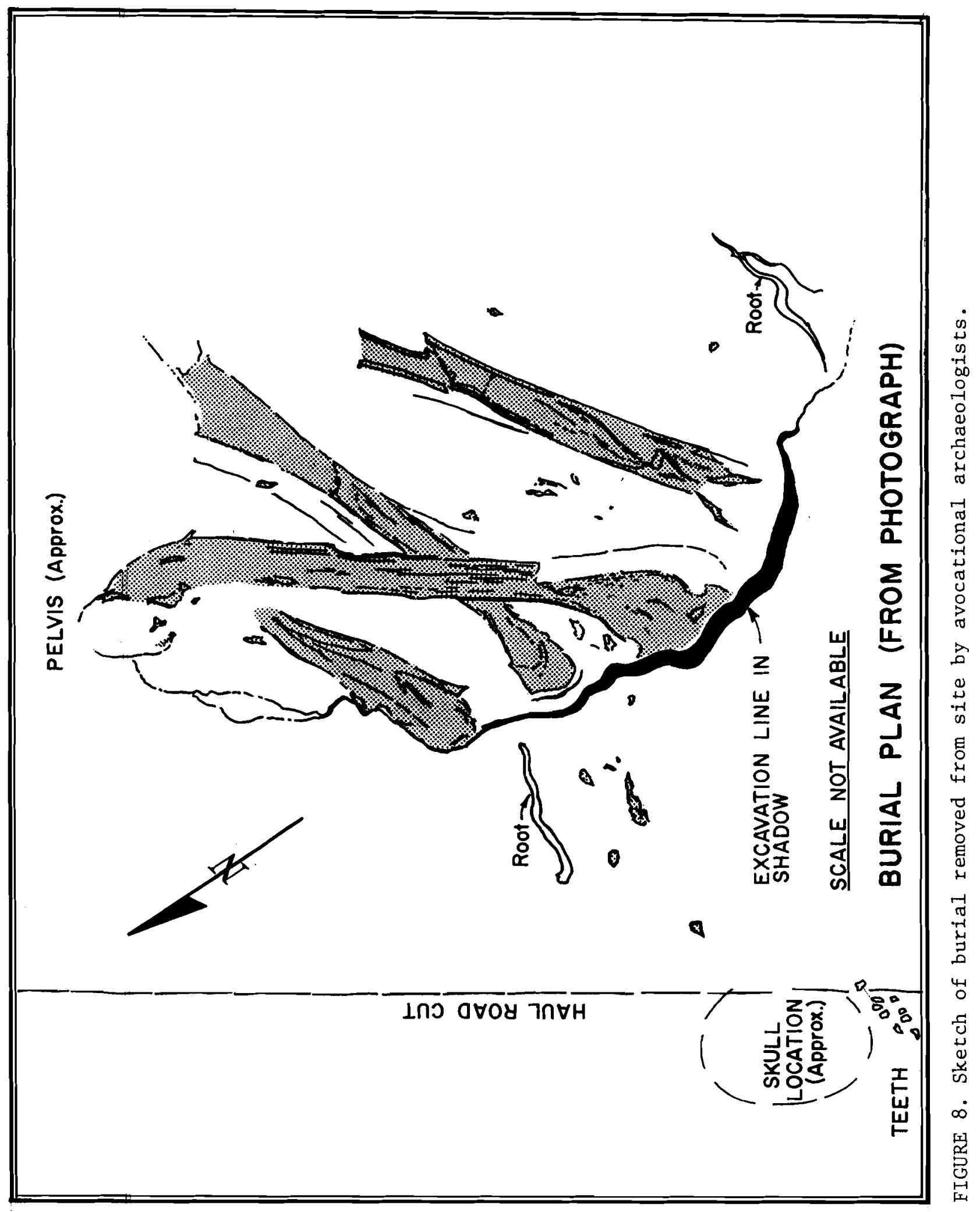




\section{ARTIFACT DISTRIBUTION}

On the basis of information gathered during the test, the site has two definite prehistoric components and a historic component. The Late Prehistoric and historic components appear to be mixed over the entire site, and separation of the two components does not appear to be possible. The Archaic prehistoric component is somewhat separate from the two later components only in Test Unit 1 and possibly in Test Unit 4. Separation of all components in Test Units 2 and $\mathbf{3}$ was impossible due to the overall shallowness of the site in those areas.

Mixing of the components to a depth of $30 \mathrm{~cm}$ is due to recent clearing operations, to possible former agricultural practices, and to rodent disturbances. The mixed deposits were readily apparent during excavation due to soil color.

Test Units 1 and 4 contained the majority of the prehistoric materials, and a 11 basis of separation relies on these two units.

The Archaic component represents the earliest occupation indicated by the testing. Associated artifacts include a Bulverde projectile point, bifaces, cores, and a modified flake. The presence of the Pedernales and Gary types indicates a continued use of the area by Archaic people over a considerable length of time. This continued use is substantiated by the numerous artifacts recovered from the site by avocational archaeologists.

The Late Prehistoric Period, specifically the Toyah Focus of the Central Texas Aspect, is indicated by the Perdiz arrowpoint, the awl, and pottery. The pottery, however, indicates contact with southeastern or coastal cultures rather than Central Texas. 
The historic material was most numerous in Test Units 2 and 3 on the upper reaches of the slope in the shallower deposits. The presence of wire and cut nails, coupled with a range of late nineteenth and early twentieth century artifacts, indicates that this was principally a late historic occupation. The existence of buildings in the area was noted as late as 1972 when the original survey was made of the Reading Site. 


\section{INTERSITE COMPARISONS}

In comparison to archaeological data from adjacent areas, it appears that the material as represented by the Reading Site closely resembles materials recovered from the Lake Sommerville area (Peterson 1965).

Cultural materials from this area are reported to be closely similar to those from the Archaic and Late Prehistoric Periods of Central Texas, with the exception of sand-tempered pottery. It is uncertain if this is locally made pottery or trade pottery; however, it does follow the traditions more to the south and east.

To the east, at Lake Conroe, Shafer (1968) reports that cultural affiliations are principally linked to the Archaic La Harpe Aspect of East Texas, with an indigenous population during the Late Prehistoric that was marginally influenced by the Caddo culture and slightly more so by the coastal Galveston Bay area culture.

Research to the north in Robertson County (Prewitt 1975) is based on a limited amount of data but suggests that the region was visited or was influenced by cultures to the north, east, and west.

The presence of artifacts at the Reading Site similar to both eastern and western types suggests an overlap of cultures. Affiliations based on point types indicate that at least during the Archaic Period the stronger influences were to the west. 


\section{CONCLUSIONS}

Testing of archaeological Site 41BU16, the Reading Site, indicates that a significant manisfestation of the Archaic and Late Prehistoric cultures was present at the site prior to construction activities, and that a portion of the site is still present within the existing right-of-way.

The site clearly contains significant deposits with probable stratigraphic separation between the Archaic component and the Late Prehistoric component. The Archaic component is evidenced by both Central Texas and East Texas projectile point types, while the Late Prehistoric is evidenced by Toyah Focus artifacts with some probable influences from the east.

Other burials may be present within the late component which might yield information relevant to the burial practices of this late group.

Historical material as recovered indicates the possible existence of late nineteenth and early twentieth century structures or settlement. Relationship to known historic activities on the river, however, are not discernible. 
Depending upon future utilization of the remaining portion of the site, it is believed that additional testing or complete excavation of the intact deep deposits is warranted.

The potential for additional burials is indicated as well as the potential for continued study of cultural sequences from stratigraphic contexts. The potential for culturally related features, i.e., hearths, is also present, particularly at the lower, less disrupted depths.

The presence of a burial and the stratification of cultural components indicate that the Reading Site should be considered for inclusion within the National Register of Historic Places. 


\section{APPENDIX: ANALYSIS OF HUMAN SKELETAL REMAINS}

The recovered skeletal remains were removed from the site by avocational archaeologists when destruction by heavy road machinery seemed imminent. Apparently at that time, the skull, vertebral column, upper limbs, upper torso, and pelvis already had been destroyed by machinery. The recovered skeletal remains were turned over to SDHPT archaeologists along with a Polaroid photograph taken when the burial was exposed in the ground prior to removal. The excavators were interviewed by SDHPT archaeologists.

From the photograph and from verbal information, the body appears to have been tightly flexed, lying on its left side with the knees drawn up to the chest area. The long axis of the vertebral column was oriented southwest to northeast, with the skull to the southwest and the pelvic area to the northeast. No burial pit was evident in the photograph nor reported by the excavators. Neither were grave inclusions recovered.

When first encountered by SDHPT archaeologists, the burial consisted of highly fragmented lower limb bones. These bones, for the most part, were still encased in chunks of the surrounding soil matrix which was removed from the ground along with the skeletal material. An unsuccessful attempt was made at reconstructing what remained of the burial; the bones were simply too fragmentary to be put back together. Therefore, no anthropometric analysis was possible. 
REFERENCES CITED

Jelks, Edward B.

1962 The Kyle Site: A Stratified Central Texas Aspect Site in H 111 County, Texas. Department of Anthropology Archaeology Series 5. The University of Texas, Austin.

Peterson, Fredrick A.

1965 The Erwins Bridge Site at Somerville Reservoir, Burleson County, Texas. Texas Archeological Salvage Project. University of Texas, Austin.

Prewitt, Elton R.

1975 Upper Navasota Reservoir: Archeological Test Excavations at the Barkley and Louis Sadler Sites. Texas Archeological Survey Research Report 33. University of Texas, Austin.

Shafar, Harry J.

1968 Archeological Investigation in the San Jacinto River Basin, Montgomery County, Texas. Archeological Salvage Project

Paper 13. University of Texas, Austin.

Suhm, Dee Ann

1960 A Review of Central Texas Archeology. Bulletin of the Texas Archeological Society 25.

Suhm, Dee Ann, and Edward B. Jelks

1962 Handbook of Texas Archeology: Type Descriptions. Texas Archeological Society Special Publications 1 and The Texas Memorial Museum Bulletin 4. 